\title{
Analisis Pengaruh Informasi Laba Terhadap Perilaku Investor Di Pasar Sekunder
}

\author{
Farichah \\ Fakultas Ekonomi dan Bisnis - Universitas Lampung \\ Email:farichah@yahoo.com
}

\begin{abstract}
After going through initial public offering process, the company must trade its shares in the secondary market. Companies should conduct signaling to users, such as investors and potential investors by providing information that can be utilized as a basis for investment decision making. The information announced (which includes earnings information) is expected to have a quality that allows investors and potential investors to predict company performance in the future. This study was conducting to investigate investors behaviour by observing trading volume, stock returns and earnings response coeffesient (ERC) in the short and long term. This study uses data and samples from the Indonesia Stock Exchange from 2006 to 2015. Hypothesis testing is done by using multiple linear regression and independent sample t test. The result showed that earnings information give effect to trading volume, stock returns, and ERC in short term (one year after IPO) and long term (for 5 years or more after IPO). The next result in the short term the stock trading volume, stock returns, and ERC is greater when compared with the volume of stock trading, stock returns, and ERC in the long term.
\end{abstract}

Keywords: Earnings Information, Trading Volume, Stock Returns and Earnings Response Coeffesient

\begin{abstract}
Abstrak: Setelah melalui proses penawaran umum perdana, perusahaan harus memperdagangkan sahamnya di pasar sekunder. Perusahaan harus melakukan signaling kepada pengguna, seperti investor dan calon investor dengan memberikan informasi yang dapat dimanfaatkan sebagai dasar untuk pengambilan keputusan investasi. Informasi yang diumumkan (termasuk informasi laba) diharapkan memiliki kualitas yang memungkinkan investor dan calon investor untuk memprediksi kinerja perusahaan di masa depan. Penelitian ini dilakukan untuk menyelidiki perilaku investor dengan mengamati volume perdagangan, pengembalian saham dan respon pendapatan koefisien (ERC) dalam jangka pendek dan panjang. Penelitian ini menggunakan data dan sampel dari Bursa Efek Indonesia dari tahun 2006 hingga 2015. Pengujian hipotesis dilakukan dengan menggunakan regresi linier berganda dan uji t sampel independen. Hasil penelitian menunjukkan bahwa informasi laba memberikan pengaruh terhadap volume perdagangan, return saham, dan ERC dalam jangka pendek (satu tahun setelah IPO) dan jangka panjang (selama 5 tahun atau lebih setelah IPO). Hasil selanjutnya dalam jangka pendek volume perdagangan saham, return saham, dan ERC lebih besar bila dibandingkan dengan volume perdagangan saham, return saham, dan ERC dalam jangka panjang.
\end{abstract}

Kata Kunci: Informasi Penghasilan, Volume Perdagangan, Pengembalian Saham, dan Koefisien Respon Pendapatan 


\section{PENDAHULUAN}

Initial Public Offering (IPO) merupakan proses yang harus dilalui oleh perusahaan yang ingin memperdagangkan sahamnya di pasar sekunder. Harga saham di pasar perdana ditentukan oleh emiten dan underwriter, berbeda dengan harga saham di pasar sekunder, yang ditentukan melalui mekanisme penawaran dan permintaan. Dalam proses IPO, dibutuhkan peran pihak lain seperti underwriter dan auditor yang berreputasi tinggi. Peran pihak lain ini dibutuhkan juga untuk memberikan signal positif kepada para investor. Stoughton dan Zechner (1998) menyatakan bahwa underwriter memiliki dua peran kunci, yaitu mengidentifikasi calon investor dan melakukan transfer nilai dari investor kepada emiten.

Salah satu penentu keberhasilan IPO adalah peran aktif underwriter dalam menjalankan strategi, termasuk menjaga harga saham di pasar sekunder agar tidak mengalami penurunan sampai di bawah harga perdananya. Strategi ini dikenal dengan istilah stabilisasi harga, yang dilakukan selama 45 hari perdagangan (hari kerja) sejak hari pertama saham diperdagangkan di pasar sekunder (Lowery dan Schwert, 2003). Pada Bursa Efek Indonesia (BEI), aktivitas stabilisasi harga diatur oleh BAPEPAM (Peraturan BAPEPAM, No. XI.B.1), bahwa underwriter dapat melakukan stabilisasi harga saham IPO selama 30 sejak hari pertama saham diperdagangkan di pasar sekunder.

Proses IPO seringkali diwarnai dengan penyajian laba yang tinggi (Nagata, 2013), melalui discretionary accrual. Upaya ini dilakukan dengan tujuan untuk memberikan sinyal kepada investor dan calon investor, sehingga yakin bahwa perusahaan memiliki kualitas kinerja yang baik. Informasi laba sebelumnya dapat menjadi informasi awal bagi investor atau calon investor ketika ingin menilai kinerja dan memprediksi probabilitas laba perusahaan IPO di masa yang akan datang. Namun demikian, ada kemungkinan investor atau calon investor berperilaku underreact atau overreact (pesimistis atau optimistis) terhadap informasi baru yang diterima ketika informasi tersebut berbeda secara ekstrim dengan informasi awalnya.

Informasi laba mungkin bukan merupakan informasi tunggal, yang dapat mempengaruhi perilaku investor. Investor bisa mempunyai fokus perhatian lain yang mempengaruhi perilakunya dalam melakukan investasi. Pada perspektif sebelumnya, investor diasumsikan memiliki kemampuan; bertindak rasional (full rationality), memproses informasi yang tersedia, dan selalu termotivasi untuk memaksimisasi utilitas dengan sikap yang selalu menghindari risiko (risk averse) dalam pengambilan keputusan investasi. Perspektif ini berbeda dengan ilmu keuangan modern, yang menggunakan psikologi kognitif (psikoanalitis).

Perspektif ilmu keuangan modern mempunyai pandangan bahwa investor memiliki keterbatasan pemikiran (bounded rationality), investor memiliki kecenderungan untuk mencari kesenangan (kepuasan) atau kebanggaan dalam bertindak (Olsen, 2001), dan dalam perolehan informasi, investor dianggap memiliki keterbatasan dalam pemrosesan karena adanya kendala kogitif (Tversky dan Kahneman, 1986), yang cenderung bertindak heuristik dalam pengambilan keputusan (Elster, 1999; dan Hirshleifer, 2001), serta investor diasumsikan memahami resiko, sehingga tidak semua investor bersikap menghindari resiko (Slovic et al., 2004).

Perilaku investor apakah optimistis atau pesimistis terhadap informasi laba, menjadi fenomena yang terus berkembang. Pengkajian terus berlanjut karena belum terjadi kesesuaian atas temuan penelitian, misalnya temuan Bernard dan Thomas (1989, dan 
1990) dan Abarbanell dan Bernard (1992) yang mengungkapkan bahwa investor dan analis pesimis terhadap perubahan laba. Contoh lain adalah penelitian yang dilakukan oleh Bloomfield et al. (2003), Kaestner (2006), Frieder (2008) dan Alwathainani (2012), yang menjelaskan bahwa perilaku investor optimis atau pesimis disebabkan oleh kecenderungan investor yang berperilaku heuristik.

Dalam perdagangan saham IPO, peran underwriter sangat menentukan tinggi rendahnya harga saham pada tiga puluh hari pertama setelah IPO, melalui kebijakan stabilisasi. Dalam jangka pendek bisa diprediksi bahwa kinerja saham perdana mendapatkan penilaian yang tinggi dari para investor, yang menggambarkan bahwa informasi laba yang dilaporkan perusahaan mendapatkan respon positif, sehingga mendorong peningkatan nilai perdagangan saham IPO. Kondisi ini bisa terus berlangsung atau sebaliknya dalam jangka pajang, mengingat bahwa informasi laba bukan merupakan satu-satunya fokus perhatian investor sebagai dasar pengambilan keputusan investasi. Respon investor bisa dilihat dari volume perdagangan, return saham, dan earnings respon coefficient (ERC) dari saham perusahaan IPO.

Oleh karena itu, maka penting untuk dilakukan penelitian yang mampu menjawab pertanyaan apakah informasi laba berpengaruh terhadap perilaku investor, yang dilihat dari volume perdagangan, return saham dan respon investor (ERC) terhadap laba yang diumumkan oleh perusahaan IPO di pasar saham, baik dalam jangka pendek maupun jangka panjang.

Pertanyaan Penelitian. Pada saat IPO, underwriter bertanggung-jawab atas perdagangan saham perdana, termasuk menjalankan pengendalian harga saham pada periode stabilisasi. Tanggung-jawab ini dimaksudkan untuk menjaga agar harga saham perdana tidak mengalami penurunan hingga di bawah harga perdananya. Periode stabilisasi ini dilakukan selama 30 hari setelah tanggal IPO. Semakin tinggi reputasi underwriter, maka semakin besar volume perdagangan, return saham yang diterima oleh investor, dan ERC saham perusahaan IPO, sebagai cerminan dari perilaku investor setelah mempunyai informasi tentang laba yang diumumkan. Terdapat kemungkinan kondisi ini tidak terjadi pada perdagangan saham dalam jangka panjang. Hal ini disebabkan oleh kemungkinan investor mempunyai fokus baru yang bisa dijadikan dasar pertimbangan untuk memutuskan ikut serta atau tidak dalam perdagangan, di samping informasi laba yang dilaporkan oleh perusahaan.

Oleh karena itu pertanyaan penelitian dapat dirumuskan sebagai berikut; (1) Apakah informasi laba berpengaruh terhadap volume perdagangan saham?; (2) Apakah informasi laba berpengaruh terhadap return saham?; (3) Apakah informasi laba berpengaruh terhadap ERC?; (4) Apakah volume perdagangan, return dan ERC saham perusahaan dalam jangka pendek lebih besar dari pada jangka panjang?

\section{KAJIAN TEORI}

Landasan Teori. Beberapa teori yang mendasari perilaku investor dalam pengambilan keputusan dan hubungannya dengan informasi laba dapat diuraikan dalam penjelasan berikut ini.

Signalling Theory. Signalling theory mengasumsikan bahwa terdapat asimetri informasi antara manajer dan investor. Manajer dipandang memiliki informasi tentang perusahaan 
(inside information) yang tidak dimiliki oleh investor. Oleh karena itu manajer berusaha untuk memberikan informasi yang dapat digunakan oleh investor dalam pengambilan keputusan, antara lain dengan menggunakan laba dan/atau dividen. Perilaku investor dipengaruhi informasi yang disignalkan oleh manajemen di pasar. Investor akan bereaksi terhadap signal yang diberikan karena mereka percaya terhadap kualitas perusahaan pemberi signal tersebut. Seorang manajer harus memiliki motivasi untuk mengungkapkan informasi yang dimiliki, agar diinterpretasikan oleh para investor dan calon investor sebagai sinyal positif dari kinerja perusahaan. Pengungkapan informasi juga perlu dilakukan untuk mengurangi asimetri informasi yang terjadi dalam kontrak antara perusahaan dan investor berkaitan dengan perdagangan saham. Salah satu cara untuk mengurangi asimetri informasi adalah dengan penerapan konsep fair value (Suryanto, 2015).Menurut Oliviera dan Taques (2016) informasi yang disajikan dalam laporan keuangan mungkin bisa membantu dalam memahami harga saham, dan menjadi faktor penentu bagi investor dalam melakukan ekspektasi return masa depan. Hartono (2010) menyatakan bahwa pengumuman terhadap suatu informasi akan menjadi sinyal yang baik atau buruk, tergantung pada interpretasi investor dalam pengambilan keputusan. Jika informasi yang diumumkan diinterpretasikan sebagai sinyal yang positif, maka akan terjadi perubahan volume perdagangan saham.

Belief-Adjustment Theory. Faktor lain yang dapat mempengaruhi perilaku individu dalam pengambilan keputusan adalah keyakinan (beliefs), yang sangat dipengaruhi oleh informasi yang tersedia. Oleh karena itu dapat disimpulkan bahwa informasi dapat mengubah keyakinan seseorang. Beaver (1989) menyatakan bahwa perilaku pengambilan keputusan akan berubah pada saat tersedia informasi baru yang dapat mengubah keyakinan. Teori yang dinyatakan oleh Hogarth dan Einhorn's (1992), mengasumsikan bahwa dalam memproses informasi, seorang individu melakukan secara bertahap dan memiliki keterbatasan kapasitas memori. Oleh karena itu, individu akan mengubah keyakinannya melalui proses anchoring dan penyesuaian. Anchor merupakan keyakinan awal yang dimiliki oleh individu yang kemudian disesuaikan ketika informasi baru tersedia. Informasi laba sebelumnya dapat menjadi anchor pada diri investor ketika ingin menilai dan memprediksi probabilitas laba di masa yang akan datang. Namun demikian, investor mungkin akan berperilaku pesimis terhadap informasi baru yang diterima ketika informasi tersebut berbeda secara ekstrem dengan nilai awalnya.

Cognitive Bias Theory. Dalam memproses informasi, investor dianggap memiliki kendala, yaitu keterbatasan dalam pemrosesan karena adanya kendala kogitif (Simon,1956), dan bias kognitif (Tversky dan Kahneman, 1986), sehingga cenderung bertindak heuristik (melakukan short cut) dalam pengambilan keputusan (Hirshleifer, 2001; dan Elster, 1999). Tversky dan Kahneman (1974) melakukan studi tentang komponen heuristik yang dapat membuat orang bias dalam menilai dan memprediksi probabilitas, yaitu representativeness dan anchoring-adjustment. Dua komponen heuristik ini dianggap dapat menjelaskan fenomena optimistis dan pesimistis di pasar saham. Heuristik representativeness menjelaskan bahwa individu menggunakan representasi dalam menaksir nilai dan memprediksi probabilitas, sehingga cenderung mengkategorikan peristiwa, kejadiankejadian sebagai suatu bentuk atau representasi kelompok atau kelas yang telah dikenal dengan baik. Sedangkan heuristik anchoring-adjustment menganggap individu dalam melakukan estimasi, memulainya dengan nilai awal (anchor), yang disesuaikan kemudian 
dengan adanya informasi baru, walaupun estimasi juga dipengaruhi oleh ketidakpastian yang diakibatkan oleh laba ex-ante (Yeung, 2009).

Earnings Informativeness. Informasi akuntansi, termasuk informasi laba disajikan dengan tujuan untuk membantu para pengguna dalam pengambilan keputusan ekonomi. Kualitas laba dapat dilihat dari manfaat yang dirasakan oleh pengguna berkaitan dengan daya prediksi laba yang diumumkan. Daya prediksi laba akan menggerakkan sentimen pasar dalam menentukan harga saham. Tingginya kualitas laba merupakan indikasi pertumbuhan perusahaan dan rendahnya asymetri informasi yang dipicu oleh adanya masalah keagenan. Kondisi ini akan menarik investor dan calon investor dalam perdagangan saham perusahaan. Zeng dan Lu (2006) menyatakan bahwa informasi akuntansi merupakan salah satu faktor yang dapat mempengaruhi biaya modal dan harga saham. Kualitas informasi akuntansi dapat dilihat dengan dua cara, yaitu nilai manfaat yang dirasakan oleh investor dalam membuat keputusan dan validitas kontrak yang mendasari hubungan kontrak antara investor dan manajemen. Oleh karena itu informasi akuntansi memiliki dua fungsi dasar, yaitu penentuan harga dan pengaturan (Zhai dan Wang, 2016).

Perilaku Investor di Pasar Sekunder. Perilaku investor dan calon investor yang ikut aktif dalam perdagangan saham di pasar sekunder dapat dilihat dari volume perdagangan, returns, dan ERC dari saham perusahaan di bursa saham. Terdapat beberapa karakteristik perilaku investor dan calon investor dalam menanggapi informasi laba yang diumumkan di pasar sekunder. Investor dan calon investor yang rasional, mendasarkan keputusan investasi yang akan diambil pada kualitas laba yang diumumkan. Jika laba yang diumumkan memiliki daya prediksi sesuai yang diharapkan, maka informasi laba tersebut akan mendorong peningkatan volume perdagangan, returns, dan ERC dari saham perusahaan. Akan tetapi, di samping investor yang rasional, di pasar saham terdapat juga investor dan calon investor yang tidak rasional. Ketidakrasionalan investor di pasar saham menyebabkan sulitnya predictability berkaitan dengan volume perdagangan, returns dan ERC saham yang diperdagangkan.

Volume Perdagangan. Pengumuman laba akan menjadi salah satu fokus perhatian para investor dan calon investor, di samping beberapa hal yang menjadi fokus lainnya. Mengingat heterogenitas dan reaksi yang dimiliki investor adalah berbeda-beda, laba yang berkualitas pada saat IPO akan menyebabkan meningkatnya ketertarikan investor dalam keikutsertaan dalam perdagangan sehingga akan mengakibatkan meningkatnya volume perdagangan saham di pasar sekunder. Peningkatan volume perdagangan bisa juga dipicu oleh sikap irrational dari para investor dalam merespon informasi laba yang diumumkan, yang cenderung overconfidence, berperilaku heuristic dan bias representative dalam pengambilan keputusan investasi. Ketidak pastian laba ex ante juga bisa berpengaruh pada volume perdagangan karena kondisi ini akan membuat investor memberikan bobot yang lebih besar pada laba yang dilaporkan (Yeung, 2009).

Return Saham. Hartono (2010) menyatakan bahwa return saham merupakan hasil yang diperoleh dari investasi. Suharli (2005) menyatakan bahwa return saham merupakan keuntungan yang diperoleh dari kepemilikan saham yang terdiri dari dividen dan capital gain/loss. Kualitas laba dapat dilihat dari kekuatan prediksi yang dimiliki, yang mampu memberikan dasar estimasi kepada investor untuk menerima return saham sebagai return investasi yang dilakukan. Akan tetapi, jika laba yang diumumkan itu berasal dari tindakan 
manajemen laba secara agresif, akan menimbulkan kondisi ketidakpastian yang tinggi di pasar saham. Kondisi ketidakpastian ini akan berdampak negatif terhadap perilaku investor, karena kesulitan prediksi yang dialami, yang dilihat dari ketidakpastian returns saham yang akan diterima. Hal ini juga diungkapkan oleh Farichah (2017) yang menyatakan bahwa terdapat hubungan dan pengaruh negatif antara manajemen laba dengan return saham.

Earnings Respon Coefficient (ERC). Kualitas laba perusahaan dapat dilihat dari keinformatifan laba yang diumumkan. dengan melihat respon pasar, yang diukur dengan ERC, yang merupakan ukuran sensivitas saham terhadap laba yang diumumkan. ERC dapat dianggap mewakili respon pasar, misalnya perubahan harga saham, dan laba yang tidak diharapkan. Menurut Collins dan Kothari (1989), ERC dapat digunakan sebagai proksi keinformatifan laba yang identik dengan kualitas laba. Informasi laba yang berkualitas (kejutan positif) akan diikuti dengan return saham positif. Jika informasi laba dianggap tidak berkualitas (kejutan negatif) akan diikuti dengan return saham yang negatif. Akan tetapi, tidak semua perusahaan memiliki ERC yang tinggi, bahkan pengumuman informasi laba yang dianggap merupakan berita baik dapat juga direspon negatif oleh investor. Hal ini karena heterogenitas perilaku investor di pasar saham.

Pengembangan Hipotesis. Pengaruh informasi laba terhadap perilaku investor merupakan fenomena yang menarik dalam perdagangan saham. Dalam jangka pendek, setelah IPO, terdapat kecenderungan perusahaan mengumumkan laba yang mampu menarik minat investor dan calon investor untuk melakukan investasi pada perusahaan IPO, yang diharapkan akan menghasilkan penilaian positif, sehingga dapat meningkatkan harga saham. Harapan ini bisa dilihat dari usaha yang dilakukan oleh perusahaan dengan mengandalkan peran underwriter yang mampu mengendalikan harga saham dalam jangka pendek, sehingga menghasilkan abnormal return positif. Akan tetapi, perilaku investor dan calon investor sulit untuk diprediksi, apakah optimis atau pesimis terhadap laba yang diumumkan mengingat terdapat heterogenitas karakteristik investor dan calon investor dengan berbagai perilaku. Walaupun demikian, oleh karena adanya campur tangan pihak underwriter di awal perdagangan saham IPO, maka hipotesis penelitian ini dapat dirumuskan sebagai berikut:

H-1a: Informasi laba berpengaruh positif terhadap volume perdagangan dalam jangka pendek

$\mathrm{H}-1 \mathrm{~b}$ : Informasi laba berpengaruh positif terhadap return saham dalam jangka pendek

H-1c: Informasi laba berpengaruh positif terhadap earnings respon coefficient dalam jangka pendek

Beberapa bukti empiris menyebutkan bagaimana perilaku investor dalam pengambilan keputusan pada saat pengumuman laba dilakukan, seperti yang dikemukakan oleh Kandiyala dan Rau (2004) bahwa investor berperilaku overreact terhadap seasoned equity offering (SEO), sementara berperilaku underreact terhadap share repurchase. Sedangkan temuan Bernard dan Thomas $(1989,1990)$ dan Abarbanell dan Bernard (1992) menjelaskan bahwa investor dan analis underreact terhadap perubahan laba ketika memprediksi laba yang akan datang. Sementara DeBondt dan Thaler (1987) menegaskan bahwa investor overreact terhadap tingkat kinerja laba yang berkelanjutan. Shane dan Brous (2000) memberikan bukti empiris bahwa analis dan investor underreact dalam merespon pengumuman laba dan informasi lainnya (informasi bukan laba) yang 
tersedia antar pengumuman laba. Perilaku underreaction tersebut terefleksi dalam revisi ramalan analis.

Asumsi bahwa tindakan overreaction terkadang terjadi di pasar saham, masih memunculkan pertanyaan tentang apa yang mendorong munculnya peristiwa tersebut. DeBondt dan Thaler (1985) mengungkapkan bahwa partisipan pasar saham overreact terhadap laba sekarang. Pendapat ini sejalan dengan pendapat Brooks dan Buckmater (1976), dan Freeman et al (1982). DeBondt dan Thaler (1990) lebih lanjut menunjukkan bahwa perubahan ramalan laba cenderung menjadi terlalu ekstrem, relatif terhadap realisasi perubahan laba pada akhirnya. Kesimpulan tersebut menunjukkan bahwa analis berperilaku overreact, meskipun mereka tidak terkait secara langsung terhadap tindakan overreaction harga saham dalam studi-studi sebelumnya. Klein (1990) juga menguji perilaku overreaction dalam ramalan analis, yang menunjukkan bahwa ramalan laba tahunan analis terlalu optimis untuk perusahaan yang harga sahamnya menurun besar sebelumnya. Temuan ini lebih konsisten sebagai fenomena underreaction (untuk harga saham menurun) daripada overreaction sebagimana temuan DeBondt dan Thaler (1985).

Pertanyaan yang sering muncul berkaitan dengan behavioral finance adalah mengapa investor underreact terhadap perubahan laba ekstrim jangka pendek, dan overreact secara kumulatif dalam jangka panjang. Bloomfield et al. (2000) menemukan bahwa harga saham underreact terhadap informasi yang reliable (laba sekarang) dan overreact terhadap informasi unreliable (laba masa lalu) ketika investor melakukan prediksi yang dimoderasi oleh overconfidence investor. Oleh karena itu, hipoteis penelitian ini dirumuskan sebagai berikut:

H-2a: Informasi laba berpengaruh positif terhadap volume perdagangan dalam jangka panjang

$\mathrm{H}-2 \mathrm{~b}$ : Informasi laba berpengaruh positif terhadap return saham dalam jangka panjang

H-2c: Informasi laba berpengaruh positif terhadap earnings respon coefficient dalam jangka panjang

Salah satu fungsi underwriter dalam pencapaian kesuksesan IPO adalah melakukan tindakan stabilisasi harga saham perdana. Tindakan stabilisasi ini diatur oleh peraturan BAPEPAM, No. XI.B.1, tahun 1996, yang menyatakan bahwa underwriter dapat melakukan stabilisasi harga saham IPO selama 30 sejak hari pertama saham diperdagangkan di pasar sekunder. Kebijakan stabilisasi ini diperkirakan mampu mempengaruhi minat investor untuk ikut serta dalam perdagangan saham perusahaan IPO di pasar sekunder. Oleh karena itu hipotesis penelitian ini dapat dirumuskan sebagai berikut:

H-3: Dalam jangka pendek volume perdagangan, return saham dan ERC lebih besar dibandingkan jangka panjang.

\section{METODE}

Data dan Sampel Penelitian. Sampel yang digunakan dalam penelitian ini adalah perusahaan publik non keuangan yang melakukan IPO pada tahun 2006 sampai dengan tahun 2010. Alasan tidak memasukkan perusahaan yang termasuk dalam klasifikasi sektor keuangan dalam sampel adalah karena karakteristik perusahaan keuangan berbeda dengan karakteristik perusahaan non keuangan. Data penelitian diambil dari Indonesian Capital Market Directory (ICMD) dari tahun 2006 sampai dengan tahun 2015. 
Variabel Penelitian dan Pengukuran. Penelitian ini menggunakan volume perdagangan (Vtrade), return saham (Rshare) dan ERC sebagai variabel dependen, dan informasi laba (NI) sebagai variabel independen, dengan variabel kontrol ukuran perusahaan (Size), pertumbuhan perusahaan (Growth) dan tingkat leverage perusahaan (Lev). Adapun pengukuran variabel yang digunakan akan diuraikan dalam penjelasan berikut. Variabel informasi laba (NI) diukur dengan logaritma (log) dari besaran net income tahunan yang dilaporkan oleh perusahaan satu tahun setelah IPO (jangka pendek) dan lima tahun setelah IPO (jangka panjang). Volume perdagangan (Vtrade) diukur dengan logaritma (log) dari jumlah rata-rata perdagangan saham selama satu tahun (jangka pendek) dan lima tahun setelah IPO.

Variabel return saham (Rshare) diukur dengan cumulative abnormal return (CAR) setelah satu tahun IPO (jangka pendek) dan CAR setelah lima tahun IPO (jangka panjang), dengan menggunakan rumus sebagai berikut:

\section{Keterangan:}

$$
\mathrm{CAR}_{\mathrm{i}(-5,+5)}=\mathrm{t}=-5 \sum^{+5} \mathrm{AR}_{\mathrm{it}}
$$

$\mathrm{CAR}_{\mathrm{i}(-5,+5)}=$ abnormal return kumulatif perusahaan i selama periode pengamatan 5 hari sebelum dan sesudah tanggal publikasi laporan keuangan untuk perusahaan IPO setelah 1 tahun dan setelah 5 tahun atau lebih.

$\mathrm{AR}_{\mathrm{it}}=$ abnormal return perusahaan i pada hari $\mathrm{t}$

Penghitungan AR dilakukan dengan menggunakan model market adjusted (Jones, 1999), dengan rumus:

$$
\mathrm{AR}_{\mathrm{i}, \mathrm{t}}=\mathrm{R}_{\mathrm{i}, \mathrm{t}}-\mathrm{R}_{\mathrm{m}, \mathrm{t}}
$$

Keterangan: $\mathrm{AR}_{\mathrm{i}, \mathrm{t}}=$ abnormal return perusahaan i pada periode ke- $\mathrm{t}$

$\mathrm{R}_{\mathrm{i}, \mathrm{t}} \quad=$ Return perusahaan pada periode ke- $\mathrm{t}$

$\mathrm{R}_{\mathrm{m}, \mathrm{t}}=$ Return pasar pada periode ke- $\mathrm{t}$

Besaran abnormal returns dihitung berdasarkan returns saham harian dan returns pasar, yang dihitung dengan rumus:

Returns Saham Harian:

$\mathrm{R}_{\mathrm{it}} \quad=\left(\mathrm{P}_{\mathrm{it}}-\mathrm{P}_{\mathrm{it}-1}\right) / \mathrm{P}_{\mathrm{it}-1}$

Keterangan:

$\mathrm{R}_{\mathrm{it}} \quad=$ Returns saham perusahaan $\mathrm{i}$ pada hari $\mathrm{t}$

$\mathrm{P}_{\mathrm{it}} \quad=$ Harga penutupan saham i pada hari $\mathrm{t}$

$\mathrm{P}_{\mathrm{it}-1} \quad=$ Harga penutupan saham i pada pada hari $\mathrm{t}-1$.

Returns Pasar Harian:

$\mathrm{Rm}_{\mathrm{t}} \quad=\left(\mathrm{IHSG}_{\mathrm{t}}-\mathrm{IHSG}_{\mathrm{t}-1}\right) / \mathrm{IHSG}_{\mathrm{t}-1}$

Keterangan:

$\mathrm{Rm}_{\mathrm{t}} \quad=$ Returns pasar harian

$\mathrm{IHSG}_{\mathrm{t}}=$ Indeks harga saham gabungan pada hari $\mathrm{t}$

$\mathrm{IHSG}_{\mathrm{t}-1}=$ Indeks harga saham gabungan pada hari $\mathrm{t}-1$.

Sedangkan variabel ERC diukur dengan slope $\alpha_{1}$ pada model regresi antara CAR dengan UE (unexpected earnings), seperti rumus yang digunakan oleh Teets dan Wasley (1996), yaitu :

$\mathrm{CAR}_{\mathrm{it}}=\alpha_{0}+\alpha_{1} \mathrm{UE}_{\mathrm{it}}+\alpha_{2} \mathrm{R}_{\mathrm{it}}+\varepsilon_{\mathrm{it}}$

Keterangan: 
$\mathrm{CAR}_{\mathrm{it}}=$ abnormal return kumulatif perusahaan i selama perioda amatan \pm 5 hari dari pengumuman laba

$\mathrm{UE}_{\mathrm{it}}=$ unexpected earnings

$\varepsilon_{\text {it }}=$ komponen error dalam model atas perusahaan i pada perioda $\mathrm{t}$

Unecpected Earnings (UE) merupakan selisih antara laba akuntansi yang direalisasi dengan laba akuntansi yang diharapkan oleh pasar, yang dihitung dengan rumus yang digunakan oleh Kalapur (1994) :

\section{Keterangan:}

$$
\mathrm{UE}_{\mathrm{it}}=\left(\mathrm{EPS}_{\mathrm{it}}-\mathrm{EPS}_{\mathrm{it}-1}\right) / \mathrm{P}_{\mathrm{it}-1}
$$

$\mathrm{UE}_{\mathrm{it}}=$ unexpected earnings perusahaan i pada periode $\mathrm{t}$

EPS $_{\text {it }}=$ earnings per share perusahaan $\mathrm{i}$ pada periode $\mathrm{t}$

$\mathrm{EPS}_{\mathrm{it}-1}=$ earnings per share perusahaan i pada periode $\mathrm{t}-1$ sebelumnya $\mathrm{t}(\mathrm{t}-1$

$\mathrm{P}_{\mathrm{it}-1} \quad=$ harga saham sebelumnya

Variabel ukuran perusahaan (Size) diukur dengan log dari total aset satu tahun (jangka pendek) dan rata-rata total aset selama lima tahun (jangka panjang) setelah IPO. Variabel pertumbuhan perusahaan (Growth) diukur dengan perubahan penjualan dalam satu tahun (jangka pendek) dan rata-rata perubahan penjualan dalam lima tahun (jangka panjang) setelah IPO. Sedangkan variabel tingkat leverage (Lev) diukur dengan rasio hutang dengan aset dalam satu tahun (jangka pendek) dan rata-rata rasio leverage lima tahun (jangka panjang) setelah IPO.

Model Penelitian. Model penelitian yang dirumuskan dalam penelitian ini adalah model I, II, dan III, untuk menginvestigasi hubungan pengaruh, baik untuk jangka pendek maupun jangka panjang, antara variabel independen terhadap variabel dependen. Model tersebut adalah :
I. $\quad$ VTrade $=a_{1}+b_{11} N I+b_{12}$ Size $+b_{13}$ Growth $+b_{14}$ Lev $+e_{1 i}$
II. RShare $=a_{2}+b_{21} N I+b_{22}$ Size $+b_{23}$ Growth $+b_{24}$ Lev $+e_{2 i}$
III. $E R C=a_{3}+b_{31} N I+b_{32}$ Size $+b_{33}$ Growth $+b_{34}$ Lev $+e_{3 i}$

Pengujian Hipotesis. Pengujian terhadap hipotesis $\mathrm{H}-1 \mathrm{a}, \mathrm{H}-1 \mathrm{~b}, \mathrm{H}-1 \mathrm{c}$, dan $\mathrm{H}-2 \mathrm{a}, \mathrm{H}-2 \mathrm{~b}$, H-2c menggunakan analisis regresi (Ordinary Least Square - OLS) untuk mengungkapkan hubungan pengaruh variabel independen terhadap variabel dependen. Sebelum semua pengujian dilakukan terlebih dahulu dilakukan pengujian asumsi klasik yang diperlukan jika analisis OLS dipergunakan dalam pengujian hipotesis. Pengujian terhadap hipotesis ini juga dilengkapi dengan penghitungan nilai $F(F$ hitung) dan nilai $\mathrm{t}$ ( $\mathrm{t}$-hitung) yang akan dibandingkan dengan nilai kritisnya. Uji $\mathrm{F}$ ini dilakukan untuk menguji apakah model yang dibangun dalam penelitian layak atau tidak. Uji t dilakukan untuk menentukan signifikansi pengaruh variabel independen terhadap variabel dependen (Gujarati dan Porter, 2009). Pengujian terhadap hipotesis 3 dilakukan dengan menggunakan compare means paired sample $t$ test. Pengujian ini dilakukan untuk menginvestigasi perbedaan antara variabel volume perdagangan (Vtrade), return saham (Rshare) dan ERC dalam jangka pendek dan jangka panjang. 


\section{HASIL DAN PEMBAHASAN}

Berdasarkan hasil pengujian dalam jangka pendek (1 tahun setelah IPO) yang dilakukan terhadap hipotesis 1a (H-1a), dapat disimpulkan bahwa informasi laba (NI) berpengaruh terhadap volume perdagangan (Vtrade). Hasil pengujian terhadap hipotesis $1 \mathrm{~b}$ (H-1b) dapat disimpulkan bahwa informasi laba (NI) berpengaruh terhadap returns saham (Rshare), dan pengujian terhadap hipotesis 1c (H-1c) menujukkan hasil bahwa informasi laba (NI) berpengaruh terhadap koefisien respon laba (ERC).

Sedangkan hasil pengujian terhadap variabel penelitian dalam jangka panjang (setelah IPO selama 5 tahun atau lebih) yang dilakukan terhadap hipotesis $2 \mathrm{a}(\mathrm{H}-2 \mathrm{a})$, dapat disimpulkan bahwa informasi laba (NI) berpengaruh terhadap volume perdagangan (Vtrade). Hasil pengujian terhadap hipotesis $2 \mathrm{~b}(\mathrm{H}-2 \mathrm{~b})$ disimpulkan bahwa informasi laba (NI) berpengaruh terhadap returns saham (Rshare), dan pengujian terhadap hipotesis 2c (H-2c) menujukkan hasil bahwa informasi laba (NI) berpengaruh terhadap koefisien respon laba (ERC).

Hasil pengujian hipotesis penelitian menunjukkan bahwa informasi laba berpengaruh positif signifikan terhadap variabel volume perdagangan saham, returns saham, dan koefisien respon laba, baik dalam jangka pendek maupun jangka panjang. Hal ini membuktikan bahwa informasi laba masih merupakan informasi keuangan yang dominan bagi investor sebagai dasar pertimbangan dalam pengambilan keputusan investasi di pasar saham, seperti diungkapkan dalam penelitian yang dilakukan oleh Wang, et al. (2013), yang menyimpulkan hubungan antara informasi akuntansi (termasuk informasi laba) dengan harga saham. Hasil penelitian ini mendukung penelitian yang dilakukan oleh Collins dan Kothari (1989) bahwa ada hubungan antara perubahan harga saham dan perubahan laba. dengan demikian ERC masih dapat digunakan sebagai proksi keinformatifan laba yang identik dengan kualitas laba.

Pengujian terhadap hipotesis $3(\mathrm{H}-3)$, yaitu untuk menguji perbedaan volume perdagangan saham (Vtrade), returns saham (Rshare), dan koefisien respon laba (ERC) dalam jangka pendek dan jangka panjang, menemukan hasil bahwa volume perdagangan saham, returns saham (Rshare), dan koefisien respon laba (ERC) dalam jangka pendek lebih besar jika dibandingkan dengan jangka panjang. Hal ini membuktikan bahwa dalam perdagangan saham dalam jangka pendek (satu tahun setelah IPO) peran underwriter masih sangat diperlukan dalam menjalankan strategi stabilisasi harga, sejak hari pertama saham diperdagangkan di pasar sekunder (Lowery dan Schwert, 2003).

Berdasarkan hasil pengujian pengaruh variabel kontrol terhadap volume perdagangan, menunjukkan hasil bahwa ukuran perusahaan (Size), memiliki hasil signifikansi pengaruh sebesar > 0,05, pertumbuhan perusahaan (Growth), dan tingkat leverage (Lev), memiliki nilai signifikansi < 0,05, maka dapat disimpulkan bahwa ukuran perusahaan (Size) tidak berpengaruh secara signifikan, pertumbuhan perusahaan (Growth), dan tingkat leverage (Lev) memiliki pengaruh positif terhadap volume perdagangan saham (Vtrade). Hasil pengujian pengaruh variabel kontrol terhadap return saham (Rshare), menunjukkan hasil bahwa ukuran perusahaan (Size) dan pertumbuhan perusahaan (Growth) memiliki signifikansi > 0,05, dan tingkat leverage (Lev) memiliki nilai signifikansi $<0,05$, maka dapat disimpulkan bahwa ukuran perusahaan (Size) dan pertumbuhan perusahaan (Growth) tidak berpengaruh, dan tingkat leverage (Lev) berpengaruh terhadap return saham (Rshare). Pengaruh variabel kontrol terhadap koefisien respon laba (ERC), menunjukkan hasil bahwa ukuran perusahaan (Size), dan 
pertumbuhan perusahaan (Growth) memiliki hasil signifikansi pengaruh sebesar $>0,05$, tetapi tingkat leverage $(L e v)$ memiliki nilai signifikansi $<0,05$, maka dapat disimpulkan bahwa ukuran perusahaan (Size), dan pertumbuhan perusahaan (Growth), tidak memiliki pengaruh terhadap ERC, dan tingkat leverage (Lev) memiliki pengaruh positif terhadap ERC.

\section{SIMPULAN}

Berdasarkan hasil pengujian dalam jangka pendek (1 tahun setelah IPO) yang dilakukan terhadap hipotesis $1 \mathrm{a}, 1 \mathrm{~b}$ dan $1 \mathrm{c}$, dapat disimpulkan bahwa informasi laba berpengaruh terhadap volume perdagangan, returns saham, dan ERC. Hasil pengujian terhadap variabel penelitian dalam jangka panjang (setelah IPO selama 5 tahun atau lebih) yang dilakukan terhadap hipotesis $2 \mathrm{a}, 2 \mathrm{~b}$, dan 2c, dapat disimpulkan bahwa informasi laba berpengaruh terhadap volume perdagangan, returns saham, dan (ERC). Pengujian terhadap hipotesis 3, menemukan hasil bahwa volume perdagangan saham, returns saham, dan ERC dalam jangka pendek lebih besar jika dibandingkan dengan volume perdagangan saham, returns saham, dan ERC dalam jangka panjang.

Berdasarkan hasil pengujian pengaruh variabel kontrol terhadap volume perdagangan, menunjukkan hasil bahwa ukuran perusahaan tidak berpengaruh, untuk pertumbuhan perusahaan, dan tingkat leverage dapat disimpulkan berpengaruh positif terhadap volume perdagangan saham. Hasil pengujian pengaruh variabel kontrol terhadap return saham menunjukkan hasil bahwa ukuran perusahaan dan pertumbuhan perusahaan tidak berpengaruh, dan tingkat leverage berpengaruh positif signifikan terhadap return saham. Pengaruh variabel kontrol terhadap ERC, menunjukkan hasil bahwa ukuran perusahaan, dan pertumbuhan perusahaan tidak berpengaruh, dan tingkat leverage berpengaruh positif terhadap ERC.

\section{DAFTAR RUJUKAN}

Abarbanell, J.S., \& Bernard, V. (1992). "Analysts' Overreaction/Underreaction to Earnings Information as an Explanation for Anomalous Stock Price Behavior". Journal of Finance. 47(3), 1181-1207.

Alwathainani, (2012). "Market Reaction to an Earnings Shock: A Test of the Conservatism Effect". The Journal of Behavioral Finance \& Economics. 2(2), 1440.

Beaver, W.H., (1989). An accounting revolution, second ed. Prentice Hall, Englewood Cliffs, NJ.

Bernard, V. L., \& Thomas, J. K. (1989). "Post-earnings-announcement drift: Delayed price response or risk premium?". Journal of Accounting Research. 27 (Supplement), 1-36.

Bernard, V. L., \& Thomas, J. K. (1990). "Evidence that Stock Prices Do Not Fully Reflect the Implication of Current Earnings for Future Earnings". Journal of Accounting and Economics. 13 (4), 305-340.

Bloomfield, R, Libby, R., \& Nelson, M.W. (2000). "Underreactions, Overreactions and Moderated Confidence". Journal of Financial Markets. 3 (2), 113-137.

Bloomfield, R, Libby, R., \& Nelson, M.W. (2003). "Do Investor Rely-on Old Elements of the Earnings Time Series?" Contemporary Accounting Research. 20 (1), 1-31.

Brooks L.D., \& Dale, A., Buckmater. (1976). "Further Evidence of the Time Series Properties of Accounting Income". The Journal of Finance. XXXI (5), 1359-1364. 
Collins, D.W., \& Kothari, S., (1989). “An analysis of intertemporal and cross-sectional determinants of earnings response coefficients". Journal of Accounting and Economics, 11 (2-3), 143-181.

De Bondt, W. F. M., \& Thaler, R. H. (1985). "Does the stock market overreact". The Journal of Finance. 40 (3), 793-805.

De Bondt, W.F.M., \& Thaler, R.H., (1990). "Do security analysts overreact?", American Economic Review. 80 (2), 52-57.

Elster, J. (1999). Alchemies Od The Mind: Rationality and The Emotion. Cambridge University Press.

Farichah, F., (2017). "Management compensation and auditor reputation on earnings management and on share returns". European Research Studies Journal. XX (3A), 196-208.

Freeman, R.N. (1987). "The Association between Accounting Earnings and Security Returns for Large and Small Firms". Journal of Accounting and Economics. 9 (2), 195-225.

Frieder, L. (2008). "Investor and Price Response to Patterns in Earnings Surprises". Journal of Financial Markets. 11 (3), 259-283

Gujarati, D. N., \& D. C. Porter. (2009). Basic Econometrics. International Edition. Singapore: McGraw-Hill.

Hartono, J. (2010). Teori Portofolio dan Analisis Investasi. Edisi Ketujuh. BPFE, Yogyakarta.

Hogarth, R.M. \& H.J. Einhorn's, (1992). “Order Effect in Belief Updating: The BeliefAdjustment Model". Cognitive Psychology. 24 (1), 1-55.

Hirshleifer, D. (2001). "Investor psychology and asset pricing". The Journal of Finance. 56 (3), 921-965.

Kaestner, M. (2006). “Anomalous Price Behavior Following Earnings Surprises: Does Representativeness Cause Overreaction?", Revue Finance. 27 (2), 5-31.

Kallapur, S. (1994). "Dividend Payout Ratio as Determinants of Earnings Response Coefficients". Journal of Accounting and Economics. 17 (3), 359-375.

Kandiyala, P. \& Rau, P.R., (2004). "Investor Reaction to Corporate Event Announcements: Underreaction or Overreaction?", Journal of Business. 77 (2), 357386.

Klein, A., (1990). "A Direct Test of the Cognitive Bias Theory of Share Price Reversals". Journal of Accounting and Economics. 13 (2), 155-166.

Lowery, M. \& G.W. Schwert. (2003). "Is the IPO pricing process efficient?”, Journal of Financial Economics, 71(1), 3 - 26.

Nagata, K. (2013). "Does Earnings Management Lead to Favorable IPO Price Formation or Further Underpricing? Evidence from Japan". Journal of Multinational Financial Management. 23 (4), 255-374.

Oliveira, J.C.T \& Taques, F.H. (2016). "Relation between Share Price and Financial Indicators in The Brazilian Stock Market". ACRN Oxford Journal of Finance and Risk Perspectives. 5 (3), 30-45.

Olsen, R.A. (2001). "Behavioral Finance as Science: Implication From the Research of Paul Slovic". Journal of Psychology and Financial Markets. 2 (3), 157-159.

Shane, P. \& Brous, P., (2000). "Investor and (Value Line) Analyst Under-reaction to Information about Future Earnings: The Corrective Role of Non-Earnings Surprise Information". Journal of Accounting Research. 39 (2), 387-404. 
Simon, H.A. (1956). "Rational Choice, and The Structure of Environment". Psychological Review. 63(2), 129-138.

Slovic, P., Finucane, M., Peter, E., \& MacGregor, (2004). "Risk as Analysis and Risk as Feelings: Some Thoughts About Affect, Reason, Risk, and Rationality". Risk Analysis,. 24 (2), 311-322.

Stoughton, N. M. \& J. Zechner. (1998). "Ipo-mechanisms, Monitoring and Ownership Structure". Journal of Financial Economics. 49 (1), 45 - 77.

Suharli, M. (2005). "Studi Empiris Terhadap Dua Faktor Yang Mempengaruhi Return Saham Pada Industri Food \& Beverages Di Bursa Efek Jakarta”. Jurnal Akuntansi \& Keuangan. 7 (2), 99-116.

Suryanto, T., (2015). "Implementation of Fair Value Accounting on Agency Problem Contract Mudharaba in Islamic Finance". International Journal of Economic Perspectives. 9 (4), 94-102.

Teets, W.R. \& C.E. Wasley. (1996). "Estimating Earnings Response Coefficients: Pooled versus Firm-Specific Models". Journal of Accounting and Economics. 21 (3), 279295.

Tversky, A. \& D. Kahneman. (1986). "Rational Choice and the Framing of Decisions". The Journal of Business. 59 (4 S2), 51-78.

Tversky, A. \& D. Kahneman. (1974). "Judgement under Uncertainty: Heuristics and Biases". The Science. 185 (4157), 1124 - 1131.

Wang, J., Fu, G. \& Luo, C. (2013). "Accounting information and stock price reaction of listed companies Empirical evidence from 60 listed companies in Shanghai stock exchange". Journal of Business \& Management. 2 (2), 11-21.

Yeung, E., (2009). "Uncertainty and expectation revisions after earnings announcements". Contemporary Accounting Research. 26 (1), 273-301.

Zhai, Jinbu \& Yutao, Wang. (2016). "Accounting information quality, governance efficiency and capital investment choice". China Journal of Accounting Research. 9 (3), 251-266

Zhang, Z., \& Liu, L. (2006). "Turnovers and stock returns: liquidity premium or speculative bubbles?" China Economic Quarterly. 5(3), 871-892. 